\title{
The Relationship between Leadership Styles and Lecturers' Job Satisfaction in Institutions of Higher Learning in Kenya
}

\author{
Henry Kiptiony Kiplangat \\ Vice Chancellor's Office, Kabarak University, Kenya
}

Copyright $\bigcirc 2017$ by authors, all rights reserved. Authors agree that this article remains permanently open access under the terms of the Creative Commons Attribution License 4.0 International License

\begin{abstract}
University management and academic staff have a critical role to diligently play in fulfilling university's mandate. Effective and efficient governance and management of both private and public universities have a direct bearing on the overall quality of the institutions. With management operating under laid down governance structures, it is crucial that specific leadership styles are adopted to make easier their roles. This paper examines the relationship between leadership styles and Lecturers' job satisfaction in higher learning institutions in Kenya. A target population of 2,773 administrators and lecturers in chartered public and private universities in Rift Valley Region of Kenya was considered. A sample of 605 participants was then obtained. The study employed convergent parallel mixed methods design with census, random and systematic sampling techniques to select the respondents. Purposive sampling was also used to select information-rich cases. Questionnaires, interview and document analysis were used for data collection. Both qualitative and quantitative data was analysed. Pearson correlation coefficient, independent-samples t-test, One-way ANOVA and regression coefficients were employed with the use of the Statistical Package for Social Science (SPSS) version 20. It was found out that benevolent authoritarian leadership style was dominantly used. However, the study recommended practice of participative leadership style.
\end{abstract}

Keywords Leadership Styles, Institutions of Higher Learning, Lecturers, Job Satisfaction

\section{Introduction}

A study by Narang and Dwivedi [16] developed a reliable and valid scale to measure the job satisfaction of knowledge workers (academicians, scientists and Information Technology (IT) professionals) in India. The findings of the study showed that fair and transparent management and competitive excellence outweighed other factors in their influence on knowledge workers' job satisfaction. Moreover, repressive management practices and supervision and guidance were the last two in order of importance, at the same time both were negatively correlated and statistically insignificant with job satisfaction. This pointed to a need to find out the leadership styles employed by university administrators and their influence on lecturers' job satisfaction in Kenya's universities.

Mahnegar and Far [13] surveyed the relationship between the Managers' leadership style and job satisfaction rate at Payame Noor University personnel, including professors and office staff, of Shush, Dezful, Andimeshk and Alvan towns of Iran in 2014-2015 academic year. The findings showed a direct and significant relationship between participative and consultative styles and the personnel job satisfaction rate. This meant the leadership quality affected institutions' different processes like decision-making, cooperation of staff, communications, constructing an appropriate and desired environment which provides personal needs and reaches the organizational goals effectively.

Job satisfaction is critical to Organizations. Among determinants of job satisfaction, leadership is viewed as an important predictor and plays a central role. Leadership styles as applied by various organizations play a vital role in promoting workplace commitment and job satisfaction. By using appropriate leadership styles, managers can affect employee job satisfaction. This paper makes reference to Prof. Rensis Likert and his colleagues at Michigan University, who assumed four types of leadership styles also known as 'Likert's Management systems': exploitative authoritarian, benevolent authoritarian, consultative and participative leadership styles [9].

\section{Exploitative Authoritarian Leadership Style}

According to Gonos and Gallo [5], exploitative 
authoritarian managers are highly autocratic/authoritative and do not trust their subordinates. They pointed out that top-down commands are the routine means of communication; decisions are exclusively made at the top of the institutions such that initiative and opinions of subordinates are disregarded and motivation is enhanced through fear and punishment, whereas rewards are seldom given. Moreover, control is the primary management strategy, objectivity is emphasized in the organization and managers tend to be insensitive to human problems and display little affection toward employees [6]. Table 1 outlines the main characteristics of exploitative authoritarian leadership style.

Exploitative authoritarian leadership style places more emphasis on performance and low emphasis on people. Therefore little interaction occurs between the supervisors, and subordinates. In such a case, job satisfaction will be limited by the fact that employee initiatives and opinions are not considered by the management, thus individuals are highly demotivated. Job satisfaction in this form of leadership is not likely to occur.

\section{Benevolent Authoritarian Leadership Style}

When the leader adds concern for people to an authoritative position, a 'benevolent authoritative' is formed. This is an improvement form over exploitative authoritarian leadership style [9]. Khan says management defines the limited boundaries for interaction, communication and decision making. Economic rewards as well as potential practical punishment are applied for staff motivation. Table 2 presents the main characteristics.

Karakas, Sarigollu, and Manisaligil [8] developed a conceptual paper in which they proposed benevolent authoritarian leadership style as a framework to incorporate principles of responsible management education to mainstream management curriculum. Their illustrative exercises, projects and processes were derived from leadership development courses in Canada and Turkey. They presented four anchors to support benevolent authoritarian leadership style: ethical sensitivity, spiritual depth, positive engagement, and community responsiveness. This study is purely theoretical. The present study sought to establish whether this style of leadership was being practiced in Kenya's chartered universities and its relationship to lecturers' job satisfaction. Although there may be some delegation of decisions in this style of leadership, almost all major decisions are still made centrally thus satisfaction of employees is moderately low.

\section{Consultative Leadership Style}

In consultative leadership, according to Mahnegar and Far [13], there is substantial but not complete confidence and trust, subordinates feel rather free to discuss matters regarding their jobs with their superior and managers usually get ideas of subordinates in solving problems. They also indicate that rewards, occasional punishment and some involvement are applied to motivate employees. The top Management has control over general decisions as well as policies, while specific decisions are delegated to lower levels [5]. Communication flows both down and up. Although downward communications are often accepted, at times, they are viewed suspiciously [9, 24]). Rad et al. [23] investigated leadership style corellates affecting Jihad-e-Keshavarzi staffs' job satisfaction in Yazd, Iran. The survey consisted of a random sample of 100 individuals. The findings showed that there was a positive and significant relationship between leadership style (leadership process, motivating factors, communication, process of decision making and characteristics of the control process) and job satisfaction. The best predictors of job satisfaction were found to be the communication and leadership processes. Table 3 presents the main characteristics of consultative leadership style. It would be worthwhile to establish whether such findings could be replicated in educational institutions situated in a different geographical location, such as Kenya.

\section{Participative Leadership Style}

According to Choi [4], a leader who embraces democratic leadership style emphasizes group participation, discussion and decisions. He makes it known that the integral feature of democratic leadership style is participation and is associated with employee productivity, satisfaction, involvement and commitment. This leadership style is similar to participative leadership style.

Khan [9] refers to participative leadership style as participative group leadership style. He describes this style as one in which motivational forces are derived from group involvement in decision and goal setting, economics and ego. "There is extensive interaction with a high degree of mutual trust and respect. Management controls are widely self-monitored, and productivity is excellent" hence "all managers should strive toward... participative style if they wish to maximize the quantity and quality of performance from employees" (p.9). More details of participative leadership style are given in Table 4.

In their study, Ogbeide and Harrington [18] assessed the relationship among participative leadership style, strategy implementation success, and financial performance in the food service industry. They used survey methodology and a random sample of 1,600 members in a USA state restaurant association. The findings showed that without consideration for industry segment or size of the firm, the direct effects of greater top management involvement and the interaction effects of three- way interaction (middle management, lower management, and frontline staff) led to higher levels of action plan success.

It was also found that higher participative approaches utilized by top management and frontline staff in the food 
service industry were significantly associated with higher financial profits and overall profits. The author wonders as to whether these findings could apply to the university education sector. In particular, could higher participative involvement by university management be significantly associated with higher levels of job satisfaction among lecturers in Kenya's chartered universities?

Similarly, according to Pardo-del-val and Lloyd [20] and Pardo-del-Val, Martínez-Fuentes, and Roig-Dobón [21], participative leadership is a style where administrators share with all the institution's staff their influence in decision making process regarding information systems, training, rewards, leadership as well as organizational culture - that is to say, that contribution in the decision making process is not confined to those with formal power or authority positions. In their study, Pardo-del-val [21] analysed the effect of participative leadership style on resistance to change and its effects on change performance. Their study population was 12,656 companies in Spain and used a random sample of approximately 1,800 companies. The tool utilized to collect data was a questionnaire.

The findings of the study suggested that participative leadership might give the members of the organization the necessary tools to question aspects that could jeopardize changes. The authors concluded that participative leadership was a knowledge broker which highlighted the sources of resistance to change that could improve the outcomes of change. Moreover, Pardo-del-val [21], found that the involvement of employees and teamwork should be resorted to as a tool so that difficulties arising from the change process would become clear and be rectified. How practical is this in educational organizations such as universities? Can participative leadership when employed by university administrators, be an instrument through which impediments to job satisfaction or causes of job dissatisfaction become evident and are corrected?

In addition, a study by Kim [11] explored the relationship between participative leadership in the context of strategic planning and job satisfaction in local government agencies in Clark County, Nevada, USA. Kim used an unspecified survey design and the instrument used to collect data was a questionnaire while the data collected were analysed using descriptive statistics and multiple regression analysis. The sample consisted of 4,097 Clark County employees.

The findings of Kim's study demonstrated a positive relationship between participative leadership style and job satisfaction. The study also emphasized effective supervisory communications as a factor influencing employee job satisfaction. Could these results be obtained from a study involving Kenya's chartered universities? Leaders who use participative leadership style improve the cognitive or affective state of followers and thus increase their job satisfaction and high job satisfaction enhances employees' psychological and physical well-being thus positively affects their performance.

\section{Materials and Methods}

The author adopted convergent parallel mixed methods design which involves both quantitative and qualitative research methods. A target population of 2,773 university management staff and lecturers in the chartered public and private universities with their main campuses in Rift Valley Region was considered. A sample size of 605 participants was then drawn using census, where a group of subjects (a sample) for study was selected from the larger group (a population). The choice of each individual was entirely by chance and each member of the population had an equal chance of being included in the sample. Systematic sampling was also used to select members from the larger target population based on a random starting point and a fixed periodic interval to allow evenly distributed sample. Purposive sampling was also used to select information-rich cases. Data collection instruments were questionnaires, interview and document analysis guides whose reliability was assessed by use of Cronbach alpha test while validity was done by help of experts' review and pilot testing. Data analysis was done by coding and categorizing qualitative data into themes while quantitative data was analysed using descriptive statistics, Pearson correlation coefficient, independent-samples t-test, One-way ANOVA and regression coefficients, with the use of the Statistical Package for Social Science (SPSS) version 20.

\section{Results}

The findings outlined in Table 5 and 6 show the deans and lecturers' responses respectively, on whether they were satisfied with their own performance.

The leadership styles adopted by the university management as expressed by the lecturers indicated the adoption of exploitative authoritarian style, benevolent authoritarian style, consultative style and participative style at $4 \%, 50 \%, 43 \%$, and $2 \%$ in that order, with benevolent authoritarian style being the dominant. On the side of the deans, exploitative authoritarian style, benevolent authoritarian style, consultative style and participative style at $2 \%, 22 \%, 70 \%$, and $4 \%$ in that order as displayed in Table 8 .

In order to establish the strength and direction of that relationship, the leadership style index was correlated with job satisfaction index using Pearsons correlation at $0.05 \%$ level of significance. The leadership style index was the summation of items that measured job satisfaction index. Correlation results for leadership style on job satisfaction were obtained and displayed in Table 9. 
Table 1. The Main Characteristics of Exploitative Authoritarian Leadership Style

\begin{tabular}{|l|l|}
\hline Leadership & $\begin{array}{l}\text { Having no confidence and trust in subordinates; } \\
\text { Subordinates do not feel at all free to discuss things about the job with their superior; and superiors seldom get } \\
\text { ideas of subordinates in solving problems. }\end{array}$ \\
\hline Motivational Forces: & Fear, threats and occasional rewards. \\
\hline Communication & $\begin{array}{l}\text { Accepted downward flow of information is viewed with suspicion and tends to be inaccurate of upward } \\
\text { communication. Superior lacks knowledge or understanding of subordinates' problems. }\end{array}$ \\
\hline Decision Making & $\begin{array}{l}\text { Bulk of decisions at top of organization; no participation of subordinates in decision making; and wrong and } \\
\text { precise information on decision making. }\end{array}$ \\
\hline Goal Setting & Orders issued; goals are overtly accepted but are covertly strongly resisted. \\
\hline Control & High concentration in top management; informal organization present; and opposing goals of formal organization. \\
\hline
\end{tabular}

Source: ([23], p.425).

Table 2. The Main Characteristics of Benevolent Authoritarian Leadership Style

\begin{tabular}{|l|l|}
\hline Leadership & $\begin{array}{l}\text { Considers confidence and trust, such as master has to servant. } \\
\text { Subordinates do not feel very free to discuss things about the job with their superior. } \\
\text { Superior sometimes gets ideas of subordinates in solving problems. }\end{array}$ \\
\hline Motivational Forces & Rewards and some actual or potential punishment. \\
\hline Communication & $\begin{array}{l}\text { Mostly downward flowing of information, accepted downward communications may or may not be viewed with } \\
\text { suspicion, information that boss wants to hear flows. Other information is restricted and filtered. } \\
\text { Superior has some knowledge or understanding of problems of subordinates. }\end{array}$ \\
\hline Decision Making & $\begin{array}{l}\text { Policy at top, many decisions within prescribed framework made at lower levels. } \\
\text { Relatively wrong information on decision making. } \\
\text { Smaller part for subordinates in decision making to create motivation. } \\
\text { Decision making contributes relatively little motivation. }\end{array}$ \\
\hline Goal Setting: & $\begin{array}{l}\text { Orders issued and opportunity to comment may or may not exist. Goals are overtly accepted but often covertly } \\
\text { resisted to at least a moderate degree. }\end{array}$ \\
\hline Control & $\begin{array}{l}\text { Relatively highly concentrated, with some delegated control to middle or lower levels. } \\
\text { Informal organization usually presents and partially resists goals. }\end{array}$ \\
\hline
\end{tabular}

Source: [25], p. 352).

Table 3. The Main Characteristics of Consultative Leadership Style

\begin{tabular}{|c|l|}
\hline Leadership & $\begin{array}{l}\text { Substantial but not complete confidence and trust. } \\
\text { Subordinates feel rather free to discuss things about the job with their superior. Superior usually get ideas of } \\
\text { subordinates in solving problems. }\end{array}$ \\
\hline Motivational Forces: & Rewards, occasional punishment and some involvement. \\
\hline \multirow{3}{*}{ Communication } & $\begin{array}{l}\text { Down and up flowing of information. } \\
\text { Downward communications often are accepted but at times viewed with suspicion; may or may not be openly } \\
\text { questioned. } \\
\text { Information that boss wants to hear flows; other information may be limited or cautiously given. } \\
\text { Superior knows and understands problems of subordinates quite well }\end{array}$ \\
\hline \multirow{2}{*}{ Decision Making } & $\begin{array}{l}\text { Broad policy and general decisions at top. More specific decisions at lower levels. Precise information for } \\
\text { decision making. } \\
\text { Decision making process results in motivation among subordinates. }\end{array}$ \\
\hline Goal Setting: & $\begin{array}{l}\text { Goals are set or orders issued after discussion with subordinate(s) of problems and planned action. } \\
\text { Goals are overtly accepted but at times with some covert resistance. }\end{array}$ \\
\hline Control & $\begin{array}{l}\text { Moderate downward delegation of review and control process; lower as well as higher levels feel responsible. } \\
\text { Information organization may be present and may be either support or partially resist goals of formal } \\
\text { organization. }\end{array}$ \\
\hline
\end{tabular}

Source: [5], p 163). 
Table 4. The Main Characteristics of Participative Leadership Style

\begin{tabular}{|l|l|}
\hline Leadership Process: & $\begin{array}{l}\text { Complete confidence and trust in all matters. } \\
\text { Subordinates feel completely free to discuss things about the job with their superior. } \\
\text { The superior always gets ideas of subordinates in solving problems. }\end{array}$ \\
\hline Motivational Forces: & Economic rewards based on compensation system developed through participation. \\
\hline Communication Process: & $\begin{array}{l}\text { Down, up and with peers flowing of information. } \\
\text { Downward communications generally are accepted but if not, openly and candidly questioned. } \\
\text { Accurate upward communication. Superior knows and understands problems of subordinates very well. }\end{array}$ \\
\hline Decision Making Process: & $\begin{array}{l}\text { Decision making widely done throughout organization, although well integrated through linking process provided } \\
\text { by overlapping groups, precise and complete information. } \\
\text { Decision making process results in motivation among subordinates. }\end{array}$ \\
\hline Goal Setting: & $\begin{array}{l}\text { Except in emergencies, goals are usually established by means of group participation. Goals are fully accepted } \\
\text { both overtly and covertly. }\end{array}$ \\
\hline Control Process: & $\begin{array}{l}\text { Quite widespread responsibility for review and control, with lower units at times imposing more vigorous reviews } \\
\text { and tighter controls than top management. } \\
\text { Informal and formal organizations are one and the same; hence all social forces support efforts to achieve } \\
\text { organization's goals. }\end{array}$ \\
\hline
\end{tabular}

Source: ([23], p.425)

Table 5. Deans' responses on Leadership Style adopted ( $\mathrm{N}=121)$

\begin{tabular}{|c|c|c|c|c|c|c|}
\hline & $\mathrm{SD}$ & $\mathrm{D}$ & Av. & A & SA & Av. \\
\hline LeadershipAttributes & $\%$ & $\%$ & $\%$ & $\%$ & $\%$ & $\%$ \\
\hline I sometimes use threats and fear to motivate & 50 & 28.8 & 39 & 6.8 & 2.5 & 5 \\
\hline Management makes all of the decisions & 25.4 & 40.7 & 33 & 14.4 & 1.7 & 8 \\
\hline I sometimes impose decisions & 34.7 & 29.7 & 32 & 19.5 & 3.4 & 12 \\
\hline Orders are issued from the top & 16.1 & 27.1 & 22 & 28.8 & 3.4 & 16 \\
\hline $\begin{array}{l}\text { Lecturers may engage in behaviours that are counter to organisational } \\
\text { goals due to exclusion }\end{array}$ & 22 & 25.4 & 24 & 21.2 & 5.1 & 13 \\
\hline motivation is based on the potential for punishment & 34.7 & 30.5 & 33 & 11.9 & 3.4 & 8 \\
\hline $\begin{array}{l}\text { Management involves us in decision making though the final } \\
\text { decision comes from them }\end{array}$ & 7.6 & 12.7 & 10 & 42.4 & 18.6 & 31 \\
\hline $\begin{array}{l}\text { There is more downward communication \&little upward } \\
\text { communication }\end{array}$ & 11 & 28 & 20 & 33.9 & 8.5 & 21 \\
\hline $\begin{array}{l}\begin{array}{l}\text { Management takes more responsibility than middle level } \\
\text { administrators and lecturers }\end{array} \\
\end{array}$ & 6.8 & 19.5 & 13 & 31.4 & 14.4 & 22.9 \\
\hline I motivate lecturers through rewards & 14.4 & 22 & 18 & 26.3 & 4.2 & 15 \\
\hline $\begin{array}{l}\text { I empower academic staff to make specific decisions that will affect } \\
\text { their work }\end{array}$ & 2.5 & 5.9 & 4 & 59.3 & 19.5 & 39 \\
\hline Management talks to lecturers before they set organisational goals & 9.3 & 21.2 & 15 & 37.3 & 8.5 & 23 \\
\hline Management allows genuine participation in making decision & 8.5 & 16.1 & 12 & 38.1 & 11.9 & 25 \\
\hline $\begin{array}{l}\text { There is free-flowing horizontal communication between } \\
\text { administrators and lecturers }\end{array}$ & 7.6 & 19.5 & 14 & 34.7 & 8.5 & 22 \\
\hline I tap into the creativity of lecturers & 3.4 & 3.4 & 3 & 57.6 & 22 & 40 \\
\hline $\begin{array}{l}\text { Management is fully aware of the problems in the lower-levels of the } \\
\text { organisation }\end{array}$ & 4.2 & 15.3 & 10 & 44.1 & 12.7 & 28 \\
\hline $\begin{array}{l}\text { Goal are accepted by everyone because they are set through } \\
\text { participative involvement }\end{array}$ & 5.9 & 19.5 & 13 & 34.7 & 12.7 & 24 \\
\hline Total Average & 16 & 22 & 42 & 28 & 10 & 29 \\
\hline
\end{tabular}


Table 6. Lecturers' Attitude on Leadership Style $(\mathrm{N}=358)$

\begin{tabular}{|c|c|c|c|c|c|c|}
\hline & $\mathrm{SD}$ & $\mathrm{D}$ & Av. & A & SA & Av. \\
\hline LeadershipAttributes & $\%$ & $\%$ & $\%$ & $\%$ & $\%$ & $\%$ \\
\hline Management uses threats and fear to motivate their lecturers & 27 & 32 & 30 & 17 & 6.7 & 12 \\
\hline Management imposes decisions on academic staff & 13 & 26.6 & 20 & 33.9 & 10.4 & 22 \\
\hline Management gives orders for the institution & 11.2 & 20.8 & 16 & 42.7 & 9.3 & 26 \\
\hline Lecturers may engage in behaviours counter to goals & 18.8 & 27.8 & 23 & 26.1 & 4.8 & 15 \\
\hline Motivation is based on the potential for punishment & 20.9 & 33.9 & 27 & 17.4 & 5.0 & 11 \\
\hline Management involves in decision making & 8.8 & 21.5 & 15 & 40.5 & 10.7 & 26 \\
\hline $\begin{array}{l}\text { There is more downward communication and little upward } \\
\text { communication }\end{array}$ & 45 & 18.8 & 32 & 43.8 & 14.9 & 29 \\
\hline Management takes more responsibility goals than lecturers & 5.6 & 13 & 9 & 48.2 & 12.4 & 30 \\
\hline Motivation of lecturers is done through rewards by management & 18 & 29.5 & 24 & 23.6 & 3.9 & 14 \\
\hline $\begin{array}{l}\text { Motivation of lecturers is done through occassional punishment } \\
\text { by management }\end{array}$ & 20.2 & 28.4 & 24 & 20.2 & 3.4 & 12 \\
\hline $\begin{array}{l}\text { Management empowers academic staff to make specific decisions } \\
\text { that will affect their work }\end{array}$ & 8 & 26.2 & 17 & 42.2 & 4.8 & 24 \\
\hline Management talks to lecturers about problems and action plan & 11.7 & 32.6 & 44 & 33.4 & 3.4 & 18 \\
\hline Management allows genuine participation in making decisions & 11.1 & 27.6 & 19 & 34.8 & 4.8 & 20 \\
\hline $\begin{array}{l}\text { There is free-flowing horizontal communication between } \\
\text { administrators and lecturers }\end{array}$ & 8.5 & 31.6 & 20 & 32.5 & 4.8 & 19 \\
\hline Management taps into the creativity of lecturers & 8.9 & 24.6 & 17 & 39.4 & 8.0 & 24 \\
\hline $\begin{array}{l}\text { Management is fully aware of the problems that go on in the } \\
\text { lower-levels }\end{array}$ & 10 & 20.8 & 15 & 31.9 & 10.5 & 21 \\
\hline All organisational goals are participative involvement & 14.8 & 31.1 & 23 & 22.5 & 3.1 & 13 \\
\hline Total Average & 15 & 28 & 22 & 32 & 7 & 28 \\
\hline
\end{tabular}

Table 7. Leadership Styles Employed by University Management

\begin{tabular}{|l|l|}
\hline Practice & Leadership Style \\
\hline I involve those I supervise to make decisions or buy into my negotiations. & Consultative and participative leadership styles. \\
\hline I use committees & Consultative leadership style \\
\hline $\begin{array}{l}\text { We have monthly consultative meetings with the staff unions as well as Students' } \\
\text { Governing Council }\end{array}$ & Consultative and Participative leadership style \\
\hline However, I also apply authoritarian leadership style where necessary. & Authoritarian leadership style \\
\hline
\end{tabular}

Table 8. University Leadership Style and Academic Staff Job Satisfaction

\begin{tabular}{|l|c|c|c|c|c|c|}
\hline & \multicolumn{3}{|c|}{ Deans } & \multicolumn{3}{c|}{ Lecturers } \\
\hline Leadership Style & Scale & Frequency & Percent & Scale & Frequency & Percent \\
\hline Exploitative Authoritarian & $17-33$ & 2 & 1.7 & $17-33$ & 14 & 3.9 \\
\hline Benevolent Authoritarian & $34-50$ & 26 & 21.5 & $34-50$ & 180 & 49.6 \\
\hline Consultative & $51-67$ & 85 & 70 & $51-67$ & 157 & 43.3 \\
\hline Participative & $68-85$ & 5 & 4.1 & $68-85$ & 6 & 1.7 \\
\hline
\end{tabular}

Table 9. University Leadership Style and Academic Staff Job Satisfaction Cross Tabulation

\begin{tabular}{|c|c|c|c|c|c|c|}
\hline & & \multicolumn{4}{|c|}{ Academic Job Satisfaction (Categorised) } & \multirow{2}{*}{ Total } \\
\hline & & Very Dissatisfied & Dissatisfied & Satisfied & Very satisfied & \\
\hline \multirow{4}{*}{$\begin{array}{l}\text { University leadership style } \\
\text { (categorized) }\end{array}$} & Authoritarian & 0 & 3 & 5 & 5 & 13 \\
\hline & $\begin{array}{c}\text { Benevolent } \\
\text { Authoritarian }\end{array}$ & 4 & 31 & 62 & 54 & 151 \\
\hline & Consultative & 1 & 10 & 44 & 63 & 118 \\
\hline & Participative & 1 & 0 & 1 & 1 & 3 \\
\hline \multicolumn{2}{|l|}{ Total } & 6 & 44 & 112 & 123 & 285 \\
\hline
\end{tabular}


Table 10. Correlation Matrix of Leadership Styles and Job Satisfaction

\begin{tabular}{|l|c|c|c|}
\hline & & Leadership Style & Job Satisfaction \\
\hline \multirow{3}{*}{ Leadership Style } & Pearson Correlation & 1 & $.117^{*}$ \\
\cline { 2 - 4 } & Sig. (2-tailed) & & .011 \\
\cline { 2 - 4 } & $\mathrm{N}$ & 475 & 471 \\
\hline \multirow{3}{*}{ Job Satisfaction } & Pearson Correlation & $.117^{*}$ & 1 \\
\cline { 2 - 4 } & Sig. (2-tailed) & .011 & 472 \\
\cline { 2 - 4 } & $\mathrm{N}$ & 471 & \multicolumn{2}{|c|}{} \\
\cline { 2 - 4 }
\end{tabular}

*. Correlation is significant at the 0.05 level (2-tailed).

University leadership style (categorised) was cross tabulated with academic staff job satisfaction (categorised). Cross tabulation results confirmed the dominance of benevolent authoritarian style as perceived by the lecturers. Table 10 presents cross tabulation results.

The study further tested a null hypothesis $\mathrm{H}_{0}$ which stated that there is no significant relationship between university leadership style and lecturers' job satisfaction. The results of the hypothesis indicated that there was a weak but positive relationship between leadership style and job satisfaction and was statistically significant $(\mathrm{r}=0.117, \mathrm{p}=0.011)$. The $\mathrm{p}$ value of leadership style is 0.011 which is less than 0.05 and indicates that; overall, the model applied is significantly good enough in predicting the outcome variable. The correlation results indicated significance in relationship $(\mathrm{r}=$ $0.117, \mathrm{p}=.011$ ), hence the null hypothesis $\mathrm{H}_{0}$ was not accepted. It was thus concluded that the study finding was statistically significant.

\section{Discussion}

According to the deans' responses, a management that is highly participative is portrayed. The academic atmosphere is warm where respect and motivation thrives. The majority of the deans rated themselves very highly in the tested skills. This creates a conducive work environment which raises staff motivation, hence, job satisfaction. On the other hand, lecturers' responses on their satisfaction with management's style are displayed in Table 6.

The findings of the study clearely indicate that management did not use threats and fear to motivate the lecturers. The deans' response depict $50 \%$ and $28.8 \%$ indicating strongly disagree and disagree respectively, with an average of $39 \%$. Thus, The lecturers' also portaryed similar results on the same with the majority, $27 \%$ and $32 \%$, indicating strongly disagree and disagree correspondingly at an average of $30 \%$. This is therefore a good indication of steering away from dissatisfiers and moving towards job satisfaction because fear creates anxiety and destroys confidence, a culture of fear can be debilitating to the employee.

Majority of the deans $(25.4 \%$ and $40.7 \%)$ strongly disagreed and disagreed respectively, with an average of $33 \%$ to the aspect of management making all of the decisions.
From this, it is clear that management had an inclusive approach in decision making which is an indication of good leadership and job satisfaction. The findings concur with those of Amzat and Idris [1] who discussed the effect of management and decision making styles on the job satisfaction of academic staff in a Malaysian Research University. Management did not impose decisions on academic staff. This is evident in the deans' responses of strongly disagree and disagree at $34.7 \%$ and $29.7 \%$ respectively, with an average of $32 \%$. The reaction from lecturers was different as $13 \%$ strongly disagreed and $26.6 \%$ disagree, with an average of $20 \%$ while majority $(33.9 \%$ and $10.4 \%$, indicated agree and strongly agree, with an average of $22 \%$. There was an element of imposing decisions on academic staff as seen in the lecturer's responses. This implied that decision making in the university management lacked the element of inclusiveness, which is one of Herzberg's dissatisfiers that affects job satisfaction. In a similar finding, in the context of the Malaysian research universities, many complaints were received from the staff about being ignored and left out in the decision-making activity and expressing particular dissatisfaction with the university management as well as its decision making styles [10].

Based on the deans' responses with an average of $22 \%$ disagreeing, the study concluded that management did not issue orders from the top. Whether "management gives orders for the institution" was probed and $11.2 \%$ of lecturers indicated strongly disagree and $20.8 \%$ indicated disagree, with an average of $16 \%$. The majority were those who agreed with the statement, $42.7 \%$ and $9.3 \%$ indicated agree and strongly agree respectively, with an average of $26 \%$. The study therefore established that, according to the lecturers, management gave orders for the institution. Research conducted in the private sector as well as in the public sector organizations of Bahawalpur City with the objective of knowing the factors that affect job satisfaction had 150 employees respond to a questionnaire. They found that employee empowerment had a significant positive relationship and it contributed more than $37 \%$ of job satisfaction. Therefore, when an employee is given autonomy in business decisions, then his satisfaction level will rise [7].

Dean's and lecturers' opinions on whether lecturers may have engaged in behaviours that were counter to 
organisational goals due to exclusion showed majority indicating strongly disagree and disagree at $22 \%$ and $25.4 \%$ in that order, with an average of $24 \%$. The aspect of lecturers engaging in behaviours counter to goals was considered and attracted the following reactions from lecturers: $18.8 \%$ and $27.8 \%$ of lecturers showed strongly disagree and disagree in that order, with an average of $23 \%$ while $26.1 \%$ and $4.8 \%$ showed agree and strongly agree respectively, with an average of $15 \%$. Hence, the study, contrary to earlier findings on exclusiveness, established that management included lecturers in decision making, therefore lecturers did not engage in behaviours that were counter to organisational goals due to exclusion, which is a great step towards job satisfaction.

Kipkebut [12] points out that consultation with, and participation by academics in decision making help them feel part of the organization and gives them a sense of ownership in the outcome of those decisions. Recent reform initiatives have focused on the autonomy of academic staff and their participation in decision making in universities. The private sector and research conducted in universities have identified the importance of worker/academic staff autonomy. This autonomy leads to a sense of ownership and empowerment where workers aim to grow within their profession and seek increased responsibility commensurate with their status [10].

Whether "motivation was based on the potential for punishment" was also scrutinized by seeking the deans' responses to it. Majority of the respondents strongly disagreed and disagreed by $34.5 \%$ and $30.5 \%$ respectively, with an average of $33 \%$ while the agree and strongly agree had $11.9 \%$ and $3.4 \%$ respectively, with an average of $8 \%$. The study also sought to find out the lecturers' opinion on whether motivation was based on the potential for punishment with majority strongly disagreeing and disagreeing at $20.9 \%$ and $33.9 \%$ respectively. The study therefore established that, according to the lecturers and deans, motivation was not based on the potential for punishment. This does not in any way encourage job satisfaction as it is known that punishment can create fear in the workplace. A negative effect of this is that creating a fearful environment does not serve to motivate employees. In fact, as a result of managers that use punishment and fear tactics, companies may experience declines in productivity, poor morale, high turnover, and lost profits [2]. Punishment techniques serve to increase a supervisor's role ambiguity while also having a negative effect on employee job performance and job satisfaction [3]. Punishment leads to fear, psychological tension and anxiety, which may interfere with the worker's desire to behave properly. After being punished, a worker actually may want to behave properly, but this desire could be short-circuited by the worker's anxieties [15].

The findings on whether management involves in decision making were positive as indicated by $42.4 \%$ and $18.6 \%$ agreeing and strongly agreeing, with an average of $31 \%$. Interview with one Registrar confirmed this finding when he disclosed his style of leadership as participative and consultative as follows: "Participative leadership style involves the stakeholders. It applies to those under me. I involve them to be part and parcel of decision-making hence ownership. In consultative leadership style, I consult the DVC (A \& F) prior to taking action" (R2, personal communication, December 9, 2014).

Page [19] observed that no longer can a few decide from their limited perspective, while the masses wait. He continues to say that in the information age, collective team brain power is better than concentrated compliance in making or carrying out decisions. Team brain power is found to be engaged in management performance. This leads to motivation and ownership of the institutions' policies.

Majority of the deans also opined that there was more downward communication and little upward communication in the instituions. This is evident by an average of $20 \%$ disagreeing while an average of $21 \%$ showed agreement to this aspect. The lecturers on the other hand expressed a different opinion with an average score of $32 \%$ while an average of $29 \%$ portrayed agreement with the aspect of management. Having more downward communication and little upward communication was a sign of exclusiveness in decision making by management, which does not go well with raising the levels of job satisfaction.

When employees are side-lined from the decision making process, their commitment and job satisfaction decline. The data analysis and interviews confirmed that employees from public universities were dissatisfied with decision making process [12]. Public universities should therefore consider formulating communication policies that are open and integrated with other HR policies, and have a "listening" hierarchy that allow employees the opportunity to offer ideas and suggestions [16], cited in [12].

The findings also show majority agreeing that management took more responsibility goals than lecturers. This implies that university management does not actively involve academic sfaff in management affairs. This was a possible source of job dissatisfaction. However, the reason for management taking up more responsibility could be an informed decision as Mapesela and Hay [14] observed that the major drawbacks in a South African university were poor top management - academic staff communication, too much decentralization of issues to faculties and departments, and too much autonomy vested on them with limited monitoring and co-ordination.

Majority scores of $59.3 \%$ and $19.5 \%$ of the deans agreed and strongly agreed respectively; with an average of $39 \%$ that management empowered academic staff to make specific decisions that would affect their work. This was considered and attracted the following reactions from lecturers; $8 \%$ and $26.2 \%$ showed strongly disagree and disagree in that order, with an average score of $17 \%$ while $42.2 \%$ and $4.8 \%$ showed agree and strongly agree respectively, with an average of $24 \%$. Hence, the study found that management empowered academic staff to make 
specific decisions that will affect their work, which is the right step towards achievement of academic staff job satisfaction. Visionary leaders empower their people. Lecturers' satisfaction and their motivation are considered a primary requisite for any successful teaching and learning process. It is generally believed that if the academic staff attains adequate freedom, autonomy and enough job satisfaction, they would be in a position to fulfil the educational objectives and national goals [1].

The study also established that management did not talk to lecturers before setting organisational goals, an exclusion policy that did not promote job satisfaction. To counter this finding was a Registrar's positive response to the inquiry about the extent to which the university management had clearly communicated the institution's vision, mission, strategy and objectives: This is done in all the university documents. Our Strategic Plan (2014-2019) and sixteen policies have been launched. This information is with the staff. The UMB communicated with the Deans who in turn communicated with the HoDs who ultimately reached the staff with the information. The university is also embarking on ISO 9001:2008 QMS. This is ongoing and the DVC (A \& F) is the Management Representative (MR). Sensitization of Governing Council (GC), Management, senior level staff, middle grade staff, junior staff and all students is in progress. This process communicate our institution's vision, mission, strategy and objectives which are also contained in the following university's documents: University Statutes; Financial Management Policy; Staff Training and Development Policy; HIV and AIDs Awareness Policy; Code of Conduct for Staff; Environmental Policy; ICT Policy; Security Policy; Anti-corruption Policy; Part-time Policy; Privately Sponsored Students Programme (PSSP) Policy; and Research and Innovation Policy. We have put them in our website. We have also reflected them in most of our documents. They are, indeed, reflected in our branding (R1, personal communication, February 23, 2015).

It is evident from the results that management allowed genuine participation in making decisions, contrary to earlier findings, which was a motivation to academic staff, hence, job satisfaction. University management and decision making styles should be flexible and consultative in their execution so as to inculcate a sense of belonging among the staff. Rigidity and bureaucracy should be eliminated in the educational system because it might lead to the academic staff developing a sense of alienation, frustration and inferiority, which could create psychological problems or trauma through feelings of desertion, discrimination or isolation from the university system [10].

More so, on free-flowing horizontal communication between administrators and lecturers; majority responses were found withthose who indicated strongly disagree and disagree at $7.6 \%$ and $19.5 \%$ in that order, with an average of $14 \%$. Those who agreed and strongly agreed had $34.7 \%$ and $8.5 \%$ respectively, with an average of $22 \%$. The study therefore established that, according to the deans, there was free-flowing horizontal communication between administrators and lecturers. The lecturers' opinion on the same indicated that there was no free-flowing horizontal communication between administrators and lecturers. This is an indication of dissatisfaction because communication creates a good working environment. Stefanovska-Petkovska et al. [26] did a research on the role of participatory management in fostering job satisfaction among public administration employees from four cities in Republic of Macedonia and found that employees who perceived that they have an effective communication with their supervisor, report higher levels of job satisfaction.

The study found that management took advantage of the creativity of lecturers. This would allow for novel ways of performing duties which is ideal for higher education, giving a sense of achievement and hence, job satisfaction.Potter [22] defined creativity as intentional thought that is imaginative, inventive, original and/or contrary to the ordinary, resulting in action that promotes new ways of thinking. Taherkhani [27] did a research with the aim of reviewing the relationship between creativity and job satisfaction of sports teachers at Takestan town. Results showed that teachers with higher degrees have more job satisfaction and creativity. This implied that creativity is an important aspect which should be rewarded and nurtured by management in order to boost job satisfaction.

Findings depict low academic staff morale. Stefanovska-Petkovska et al. [26] did a research on the role of participatory management in fostering job satisfaction among public administration employees from four cities in Republic of Macedonia and found that the use of participative leadership style by the manager is significantly associated with job satisfaction of employees in local self-government. Kipkebut [12] affirmed that when employees are sidelined from the decision making process, their commitment and job satisfaction decline.

\section{Exploitative Authoritarian Leadership Style and Job Satisfaction}

The study sought to find out from deans if they could work under an exploitative authoritarian manager for a long time. It was found that $82 \%$ of deans indicated that they could not work under an exploitative authoritarian manager. It therefore showed that any management that practiced the exploitative authoritarian leadership style had employees who did not wish to be in those institutions because they would be unhappy. The study further established that working under exploitative authoritarian manager for a long time created feelings of intimidation. The exploitative authoritarian manager was described by respondents as selfish, insensitive and inhuman. The common sentiments from the deans showed that this kind of manager set unrealistic goals, and therefore brought about feelings of suppresion, discontentment, sadness and feelings of being constricted and restricted. 
Information from Registrars R1, R6 and R3 indicated presence of authoritarian leadership style. When asked to describe the main leadership style(s) he used in the day to day performance of his duties, one Registrar responded by saying: "I mainly combine consultative and participative leadership styles. However, I also apply authoritarian leadership style where necessary" (R1, personal communication, February 23, 2015). Another Registrar said: "I like to involve my staff in major discussions, but I reserve the right to make the final decision. I talk to staff members, get their ideas and brainstorm but reserve the right to make the final decision" (R3, personal communication, December 9, 2014). In addition, a different Registrar added the following:

I use both consultative and participative leadership styles. Another style I employ is pragmatic leadership style. In this manner, I can apply any form of leadership based on the existing circumstances. I am able to deal with cases which cannot fit in the other management styles I use. Action will be determined by contingency and so I apply what is suitable depending on when and where (R6, personal communication, December 9, 2014).

In a study done in some of the Malaysian public and research universities, it was found that staff generally complain about the university management and decision making style for being exclusively directive and authoritative. In addition, after the corporatization process in some of these universities, the consequence has created a sense of hostility among the staff as expressed through their complaints at being left out from the relevant participation [10]. Exploitative authoritarian leadership style created feelings of intimidation thus low job satisfaction among lecturers.

\section{Benevolent Authoritarian Leadership Style and Job Satisfaction}

A benevolent authoritarian manager has the authoritative element dominating, although some decision-making is delegated, allows downward communication, because the leader is interested in some ideas and opinions of subordinates, thus partially tolerates them, wields strict control, and bases motivation on rewards, but also on fear and punishment. The study found that $73 \%$ deans and $57 \%$ lecturers were not in favour of working under a benevolent authoritarian manager. The researcher also obtained some of the sentiments from the qualitative section on their views on whether benevolent authoritarian managers could make lecturers working under them to enjoy high job satisfaction. Lecturers working under benevolent authoritarian leadership style could not enjoy high job satisfaction due to lack of motivation; counter productive enviroment; unconducive environment; and stressfull leadership.

\section{Consultative Leadership Style and Job Satisfaction}

The study established that consultative leadership style was the style of choice as $95 \%$ of deans and $94 \%$ of lecturers gave a resounding "yes" to the question on whether working under administrators who use consultative leadership style results into higher job satisfaction. This is an indication that higher job satisfaction is derived from working with a consultative manager. The most common reasons as to why working under administrators who used consultative leadership style was preferred are: enhancement of team spirit; value of personal skills and abilities; high ownership of decisions and ideas; and feel of more value and appreciation.

\section{Participative Leadership Style and Job Satisfaction}

Results showed that working under administrators with participative leadership style gave the highest job satisfaction as $96 \%$ of deans and $94 \%$ of respondents affirmed this. The study thus established that participative leadership style produced the highest job satisfaction. The reasons given as to why working under administrators with participative leadership style ensured the highest job satisfaction were as follows: improved morale, team work; unity in achieving goal objectives and opportunity for creativity.

Amzat and Idris [1] in their research to discussing the effect of management and decision making styles on the job satisfaction of academic staff in a Malaysian Research University, reinforced the view that leadership style and decision making style affect the job satisfaction of the academic staff. These findings were also related to findings by Kim [11] who explored the relationship between participative leadership in the context of the strategic planning and job satisfaction in local government agencies in Clark County, Nevada, USA. The findings demonstrated a positive relationship between participative leadership style and job satisfaction. Table 7 shows different leadership styles employed by management. In summary, working under administrators with participative leadership style gave the highest job satisfaction with the following reasons; improved morale, team work, unity in achieving goal objectives and opportunity for creativity.

\section{Conclusions}

The following was concluded on leadership style: management did not use fear and threats to motivate academic staff; management did not impose decisions on academic staff; had an inclusive approach in decision making; did not issue orders from the top; lecturers did not engage in behaviours that were counter to organisational goals due to exclusion; motivation was not based on the potential for punishment; involved deans in decision making though the final decision came from management; communication was both downward and upward; lecturers were motivated through rewards;academic was staff 
empowered to make specific decisions that would affect their work; management talked to lecturers before setting organisational goals; allowed genuine participation in making decisions; took advantage of the creativity of lecturers; was fully aware of the problems in the lower-levels of the organisation; goals were accepted by everyone because they were set through participative involvement; lecturers did not engage in behaviours counter to organisational goals; management talked to lecturers about problems and action plan; was fully aware of the problems that went on in the lower-levels and did not impose decisions on academic staff. However, deans and lecturers did not agree on four areas, namely; free flowing horizontal communication between administrators and lecturers; management taking more responsibility than middle level administrators and lecturers and, goal setting through participative involvement.

More so, the deans were found unable to work under an exploitative authoritarian manager for a long time because it created feelings of intimidation. The exploitative authoritarian manager was described as: selfish; insensitive; inhuman and an unrealistic goal setter. In addition, an exploitative authoritarian leadership style brought about feelings of suppresion, discontentment, sadness, constriction and restriction. The study also confirmed presence of authoritarian leadership style in the universities. This implied an effect on job satisfaction levels of academic staff.

Deans and lecturers were not in favour of working under a benevolent authoritarian manager with the reason that lecturers working under them could not enjoy high job satisfaction for the following reasons: lack of motivation; counter productive enviroment; unconducive environment; and lastly, stressfull leadership.

Consultative leadership style was the style of choice for deans and lecturers because it produced higher job satisfaction with the following reasons; enhancement of team spirit, value of personal skills and abilities, high ownership of decisions and ideas and, feel of more value and appreciation.

\section{Recommendations}

Participation in decision making and information sharing processes should be reviewed by management because academic staff's participation in decision making, as per this study, is wanting. It is, therefore, recommended that management reconsiders its decision making policies and ensures ownership of decisions made.

\section{REFERENCES}

[1] Amzat, I. H., \&Idris, D. A. R. (2012). Structural Equation Models of Management and Decision-making Styles with Job
Satisfaction of Academic Staff in Malaysian Research University. International Journal of Educational Management, 26 (7), Retrieved from http://dx.doi.org/10.1108/09513541211263700.

[2] Casison, J. (2002). Scare tactics. Incentive, 176, 56 - 62.

[3] Challagalla, G. N., \& Shervani, T. A. (1996). Dimensions and types of supervisory control: Effects on salesperson performance and satisfaction. Journal of Marketing, 60, 89 105.

[4] Choi, S. (2007). Democratic leadership: The lessons of exemplary models for democratic governance. International Journal of Leadership Studies, 2(3), 243 - 262.

[5] Gonos. J., Gallo. P. (2013).Model for leadership style evaluation. Management, 18(2), $157-168$.

[6] Hoyle, J. R. (2012). Leadership Styles. In J. R. Hoyle (Ed.). Encyclopaedia of Educational Leadership and Administration. (pp. 595 - 598). Thousand Oaks, CA: Sage.

[7] Javed, M., Balouch R., \& Hassan, F. (2014).Determinants of Job Satisfaction and its Impact on Employee Performance. International Journal of Learning and Development. 4(2), 120 -140 .

[8] Karakas, F., Sarigollu, E., \& Manisaligil, A. (2013).The use of benevolent leadership development to advance principles of responsibilities management education. Journal of Management Development, 32(8), 801 - 822.

[9] Khan, A. (2010). The Dilemma of Leadership Styles and Performance Appraisal: Counter Strategies. Journal of Managerial Sciences, 4(1), 1 - 8.

[10] Khetarpal, I. K., \& Srivastava R. C. (2000). Management styles grounded in interpersonal roles. International Journal of Educational Management, 14(2), 74 - 83.

[11] Kim, S. (2002). Participative management and job satisfaction: Lessons for management leadership. Public Administration Review, 62(2), 231 - 241. Retrieved from http://www.jstor.org/stable/3109906.

[12] Kipkebut, D. J. (2010). Organisational Commitment and Job Satisfaction In higher Educational Institutions: The Kenya Case (Unpublished doctoral dissertation). Middlesex University, Middlesex, UK.

[13] Mahnegar, F., \& Far, P. (2015). Surveying the Relationship between Leadership Style and Job Satisfaction of Payam - e Noor University Personnel. International Journal on New Trends in Education and Literature, 1 (6), 22 - 36.

[14] Mapesela, M., \& Hay D. H. R. (2006). The effect of change and transformation on academic staff and job satisfaction: A case of a South African University. Higher Education, 52, 711 $-747$.

[15] Milbourn.G. (1996). Punishment in the work place creates undesirable side effects. Bizjournal Article. Retrieved from /Wichita/stories/1996/11/18/focus3.html

[16] Mulinge, M., \& Mueller, C. W. (1998). Employee Job Satisfaction in Developing Countries: The Case of Kenya. World Development, 26(12), 2181 - 2199.

[17] Narang, R., \& Dwivedi, A. (2010).Managing the Job Satisfaction of Knowledge Workers: An Empirical 
Investigation. Asia Pacific Journal of Business and Management, 1(1), 1 - 14.

[18] Ogbeide, G. A., \& Harrington, R. J. (2011).The relationship among participative management style, strategy implementation success and financial performance in the food service industry. International Journal of Contemporary Hospitality Management, 23(6), 719 - 738. doi.10.1108/0959611111115348.

[19] Page, D. (2008). Effective team leadership: Learning to lead through relationships. Nairobi: Evangel Publishing House.

[20] Pardo - del - Val, M., \& Lloyd, B. (2003). Measuring empowerment. Leadership and Organization Development Journal, 24(2), 102 - 108.

[21] Pardo - del - Val, M., Martínez-Fuentes, C., \& Roig-Dobón. (2012). Participative management and its influence on organisational change. Management Decision, 50(10), 1843-1860. doi.10.1108/00251741211279639

[22] Potter, E. M. (2013). Perceptions of Creativity among Faculty in Higher Education (Unpublished master's thesis). Grand Valley State University, USA 56.1 - 88.

[23] Rad, G. P., Esfahani, G., \& Miandashti, N. Z. (2008).Investigation of Leadership Style Correlates Affecting Jihad-e-Keshavarzi Staffs Job Satisfaction in Yazd. Journal of Agriculture, Science and Technology (JAST), 10, 421 - 429.

[24] Robbins, S. P. (2001). Organizational Behaviour (4th ed.). Upper Saddle River, New Jersey: Prentice Hall Inc.

[25] Sahni, P., \& Vayunandan, E. (2010).Administrative Theory. New Delhi: Asoke K. Ghosh, PHI Learning Private Limited.

[26] Stefanovska-Petkovska, M., Bojadziev, M., \& Stefanovska, V. V. (2014).The role of participatory management in fostering job satisfaction among public administration employees. Working Paper No. 2014/272 University American College Skopje, Maastricht School of Management.

[27] Taherkhani, E. (2015). Review of relation between creativity and job's satisfaction of physical education teachers. Cumhuriyet Science Journal, 36(3), 280 - 287. 